\title{
Hubungan Kualitas Tidur dengan Prestasi Akademik Mahasiswa Program Studi Pendidikan Dokter Angkatan 2010 FK Universitas Andalas
}

\author{
Hanafi Nilifda ${ }^{1}$, Nadjmir ${ }^{2}$, Hardisman ${ }^{3}$
}

\begin{abstract}
Abstrak
Kualitas tidur seseorang dikatakan baik apabila tidak menunjukkan berbagai tanda kekurangan tidur dan tidak mengalami masalah dalam tidurnya. Gangguan tidur banyak ditemui dikalangan dewasa muda terutama mahasiswa yang nantinya bisa menyebabkan berkurangnya konsentrasi belajar dan gangguan kesehatan. Hal ini bisa menyebabkan tidak tercapainya prestasi akademik secara optimal karena proses belajar menjadi terganggu. Tujuan penelitian ini adalah untuk menentukan hubungan kualitas tidur dengan prestasi akademik mahasiswa pendidikan dokter angkatan 2010 FK Unand. Penelitian ini menggunakan metode analitik dengan rancangan cross sectional. Total responden sebanyak 177 orang yang dipilih dengan teknik random sampling. Data kualitas tidur diambil dengan menggunakan indeks kualitas tidur Pittsburgh (PSQI) dan prestasi akademik dari nilai ujian blok 4.2. Pada akhir penelitian dilakukan uji statistik chi square untuk mengetahui hubungan kedua variabel. Hasil penelitian menunjukkan bahwa sebanyak 51 mahasiswa (65\%) memiliki kualitas tidur dan prestasi akademik yang baik, 27 mahasiswa (35\%) memiliki kualitas tidur yang baik dengan prestasi akademik yang kurang baik, 43 mahasiswa (43\%) memiliki kualitas tidur yang buruk dengan prestasi akademik yang baik, dan 56 mahasiswa (57\%) memiliki kualitas tidur yang buruk dan prestasi akademik yang kurang baik. Berdasarkan uji chi square didapatkan nilai $p=0,004 \quad(p<0,05)$. Penelitian ini menyimpulkan terdapat hubungan antara kualitas tidur dengan prestasi akademik mahasiswa pendidikan dokter angkatan 2010FK Unand.
\end{abstract}

Kata kunci: kualitas tidur, prestasi akademik, mahasiswa kedokteran

\section{Abstract}

The good quality of sleep is there is no any disturbance in their sleep. The condition of sleep disorders commonly found among young adults, especially college students who can later cause a reduction in the concentration of learning and health problems. This can lead to failure to achieve optimal academic achievement because learning becomes impaired. The objective of this study was to determine the relationships between sleep quality and academic achievement on medical education student class of 2010 medical faculty of Andalas University. This research used analytic methods with cross sectional design. Total of 177 respondents were selected by random sampling technique. Sleep quality using the Pittsburgh Sleep Quality Index (PSQI) and the academic achievement of test scores 4.2 blocks. At the end of the study, conducted chi-square test to determine the relationship between the two variables. The results showed that as many as 51 students (65\%) have quality sleep and good academic achievement, 27 students (35\%) had a good sleep quality with poor academic achievement, 43 students (43\%) had poor sleep quality with good academic achievement, and 56 students (57\%) had poor sleep quality and poor academic achievement. Based on chi square test $p$ value $=0,004(p<0,05)$. The study concluded there is a relationship between sleep quality with academic achievement for medical education student class of 2010 medical faculty of Andalas University.

Keywords: sleep quality, academic achievement, medical students 
Affiliasi penulis: 1. Pendidikan Dokter FK UNAND (Fakultas Kedokteran Universitas Andalas Padang), 2. Bagian IImu Psikiatri FK UNAND, 3. Bagian IImu Kesehatan Masyarakat FK UNAND

Korespondensi: Hanafi Nilifda, JI. Perintis Kemerdekaan No.138, Padang, email:hanafinilifda@gmail.comTelp: 085355161702

\section{PENDAHULUAN}

Tidur merupakan kebutuhan dasar setiap orang. Pada kondisi istirahat dan tidur, tubuh melakukan proses pemulihan untuk mengembalikan stamina tubuh hingga berada dalam kondisi yang optimal. ${ }^{1}$ Perubahan pola tidur umumnya disebabkan oleh tuntutan aktivitas sehari-hari yang berakibat pada berkurangnya kebutuhan untuk tidur, sehingga sering mengantuk yang berlebihan di siang harinya. ${ }^{2}$

Kebutuhan tidur yang cukup tidak hanya ditentukan oleh faktor jam tidur (kuantitas tidur), tetapi juga oleh kedalaman tidur (kualitas tidur). ${ }^{3}$ Kualitas tidur meliputi aspek kuantitatif dan kualitatif tidur, seperti lamanya tidur, waktu yang diperlukan untuk bisa tertidur, frekuensi terbangun dan aspek subjektif seperti kedalaman dan kepulasan tidur. ${ }^{4}$ Kualitas tidur dikatakan baik jika tidak menunjukkan tanda-tanda kekurangan tidur dan tidak mengalami masalah dalam tidur.K ondisi kurang tidur banyak ditemui dikalangan dewasa muda terutama mahasiswa yang nantinya bisa menimbulkan banyak efek, seperti berkurangnya konsentrasi belajar dan gangguan kesehatan. ${ }^{5}$

Kurangnya kebutuhan tidur akan berdampak pada menurunnya kemampuan untuk berkonsentrasi, membuat keputusan dan berpartisipasi dalam aktivitas sehari-hari. Dewasa muda yang mengalami hambatan dalam proses belajar disebabkan oleh rasa mengantuk dan lelah akibat kurang tidur, sehingga konsentrasi belajar menurun. Hal ini perlu mendapatkan perhatian yang serius karena gangguan tidur (sleep deprivation) dapat mempengaruhi proses belajar, gangguan memori dan kesehatan emosi. ${ }^{6}$ Konsentrasi yang baik dapat memperoleh hasil prestasi belajar yang memuaskan. ${ }^{6,7}$

Berdasarkan uraian di atas, perlu diidentifikasi hubungan kualitas tidur mahasiswa pendidikan dokter angkatan 2010 FK Unand dengan prestasi akademik yang diperoleh. Penelitian kualitas tidur terhadap mahasiswa kedokteran karena ilmu kedokteran mempelajari hal yang kompleks dan terintegrasi sehingga mahasiswa dituntut untuk memahami ilmu tersebut. Mahasiswa harus banyak belajar dari sumber rujukan, apalagi FK Unand menganut sistem PBL (Problem Based Learning) dimana mahasiswa lebih aktif dalam proses belajar yang dikenal dengan istilah adult learning. Dalam sistem PBL, mahasiswa mempunyai beban kuliah yang sama dan mendapat perlakuan yang sama sehingga penelitian akan lebih berimbang dan mudah dilakukan. Pada sistem ini, ujian diadakan satu kali tiap tujuh minggu yang dikenal dengan istilah ujian blok. Nilai akhir mahasiswa merupakan gabungan dari 3 komponen, yaitu ujian tulis $(60 \%)$, ujian skills lab (20\%) dan diskusi tutorial $(20 \%)$, sehingga prestasi akademik memenuhi segala aspek yang ada, yaitu pemecahan tulisan dari penilaian ujian tulis, penilaian lisan dari diskusi tutorial dan keterampilan dari penilaian skills lab.

Namun, banyak mahasiswa yang mengeluh mengantuk ketika perkuliahan berlangsung bahkan sering ditegur oleh dosen dan kurang aktif dalam diskusi tutorial.Selain itu, banyak mahasiswa yang tidak menghadiri perkuliahan di pagi hari, terutama jam tujuh pagi dengan keluhan mengantuk.Keluhan ini nantinya bisa mempengaruhi prestasi belajar mahasiswa sehingga perlu menjadi pertimbangan kita bersama. Disamping itu, alasan penulis mengambil sampel angkatan 2010 dikarenakan angkatan 2010 merupakan angkatan semester terakhir di tahap pendidikan sarjana kedokteran, yaitu semester VII yang sudah melalui berbagai proses pendidikan preklinik di FK Unand. Selain itu, berdasarkan penelitian yang telah diuraikan sebelumnya, secara epidemiologi kelompok usia yang terbanyak mengalami gangguan tidur adalah usia 19-29 tahun. Hal ini sesuai dengan usiamahasiswa angkatan 2010 yang berusia rata-rata 20-22 tahun. Prestasi akademik adalah IPblok 4.2, sebab penelitian ini mengidentifikasi gangguan tidur yang dialami minimal dalam satu bulan terakhir yang terjadi secara berulang dan waktunya bersamaan dengan berlangsungnya blok 4.2 sehingga hasilnya akan lebih akurat.

Penelitian ini diharapkan dapat diambil suatu pelajaran yang berharga, terutama bagi mahasiswa angkatan 2010 agar bisa mencapai kualitas tidur yang baik dan menjadi evaluasi bagi angkatan 2011, 2012 dan 2013 sehingga nantinya bisa mendapatkan prestasi akademik yang memuaskan. 


\section{METODE}

Ini adalah penelitian analitik dengan rancangan cross sectional untuk mengetahui hubungan antara variabel independen dengan variabel dependen dengan melakukan pengukuran sewaktu. Penelitian ini dilakukan dari Desember 2013 sampai Januari 2014.

Populasi dalam penelitian ini merupakan mahasiswa angkatan 2010 FK Unand dengan jumlah sampel sebanyak 177 orang. Pengambilan sampel dilakukan dengan menggunakan teknik random sampling dimana setiap orang mempunyai kesempatan yang sama menjadi responden.

Kualitas tidur mahasiswa diukur dengan menggunakan Indeks Kualitas Tidur Pittsburgh (PSQI) yang terdiri dari 18 pertanyaan. Prestasi akademik diambil dari nilai ujian blok 4.2 semester VII. Data penelitian diolah menggunakan uji statistik chi-square dengan derajat kepercayaan 95\%. Bila $p<0,05$ maka hasil perhitungan secara statistik menunjukkan adanya hubungan bermakna antara kedua variabel.

\section{HASIL}

Berdasarkan penelitian yang telah dilakukan terhadap 177 responden, didapatkan sebanyak 78 orang (44\%) memiliki kualitas tidur yang baik dan 99 orang (56\%) memiliki kualitas tidur yang buruk, seperti yang dapat dilihat pada Tabel 1 .

Tabel 1. Gambaran kualitas tidur mahasiswa

\begin{tabular}{ccc}
\hline Kualitas Tidur & f & $\%$ \\
\hline Baik & 78 & 44 \\
Buruk & 99 & 56 \\
Total & 177 & 100 \\
\hline
\end{tabular}

Penilaian kualitas tidur responden dibagi atas 7 komponen, yaitu kualitas tidur subjektif, latensi tidur (kesulitan memulai tidur), lama tidur, efisiensi tidur, gangguan tidur di malam hari, penggunaan obat tidur dan gangguan aktivitas di siang hari.

Tabel 2. Kualitas tidur subjektif

\begin{tabular}{ccc}
\hline Persepsi & $\mathbf{f}$ & $\%$ \\
\hline Sangat Baik & 15 & 8 \\
Baik & 95 & 54 \\
Kurang & 56 & 32 \\
Sangat Kurang & 11 & 6 \\
Total & 177 & 100
\end{tabular}

Berdasarkan distribusi frekuensi kualitas tidur subjektif didapatkan bahwa sebanyak 95 orang (54\%) memiliki kualitas tidur subjektif yang baik, 15 orang (8\%) sangat baik, 56 orang (32\%) memiliki kualitas tidur yang kurang dan hanya 11 orang $(6 \%)$ yang memiliki kualitas tidur yang sangat kurang.

Tabel 3. Latensi tidur mahasiswa

\begin{tabular}{ccc}
\hline Waktu & $\mathbf{f}$ & $\%$ \\
\hline$\leq 15$ menit & 64 & 36 \\
$16-30$ menit & 70 & 40 \\
$31-60$ menit & 29 & 16 \\
$>60$ menit & 14 & 8 \\
Total & 177 & 100 \\
\hline
\end{tabular}

Berdasarkan distribusi frekuensi latensi tidur, terlihat bahwa sepertiga responden yaitu 64 orang (36\%) memiliki latensi tidur yang sangat baik dan 70 orang (40\%) dengan latensi tidur yang baik. Kemudian, hampir seperempat responden memiliki latensi tidur yang buruk, yaitu 43 orang (24\%).

Tabel 4. Durasi tidur mahasiswa

\begin{tabular}{ccc}
\hline Waktu & $\mathbf{f}$ & $\%$ \\
\hline$>7$ jam & 31 & 18 \\
$6-7$ jam & 96 & 54 \\
$5-6$ jam & 34 & 19 \\
$<5$ jam & 16 & 9 \\
Total & 177 & 100 \\
\hline
\end{tabular}

Berdasarkan distribusi frekuensi durasi tidur didapatkan bahwa sebanyak 31 orang (18\%) yang memiliki durasi tidur yang cukup, sedangkan yang memiliki durasi tidur yang kurang sebanyak 146 orang (82\%), 16 orang (9\%) diantaranya sangat kurang.

Tabel 5. Efisiensi tidur mahasiswa

\begin{tabular}{ccc}
\hline Efisiensi & $\mathbf{f}$ & $\%$ \\
\hline$>85 \%$ & 172 & 97 \\
$75-84 \%$ & 5 & 3 \\
$65-74 \%$ & 0 & 0 \\
$<65 \%$ & 0 & 0 \\
Total & 177 & 100 \\
\hline
\end{tabular}

Efisiensi tidur merupakan perbandingan lama tidur yang sebenarnya dengan lama berada di tempat tidur. Dari hasil penelitian didapatkan bahwa hampir seluruh responden memiliki efisiensi tidur yang baik, 
yaitu sebanyak 172 orang (97\%) dan hanya 5 orang (3\%) dengan efisiensi tidur yang kurang baik.

Tabel 6. Gangguan tidur malam hari

\begin{tabular}{ccc}
\hline Gangguan Tidur & $\mathbf{f}$ & $\%$ \\
\hline Tidak Ada & 35 & 20 \\
Ringan & 130 & 73,4 \\
Sedang & 11 & 6 \\
Berat & 1 & 0,6 \\
Total & 177 & 100 \\
\hline
\end{tabular}

Berdasarkan distribusi frekuensi gangguan tidur malam hari, dapat dilihat bahwa hanya 35 orang (20\%) yang tidak ada mengeluh gangguan tidur di malam hari. Sebanyak 130 orang $(73,4 \%)$ mengalami gangguan tidur ringan, 11 orang $(6 \%)$ mengalami gangguan tidur sedang dan hanya 1 orang $(0,6 \%)$ yang mengalami gangguan tidur yang berat.

Penilaian kualitas tidur yang keenam, yaitu penggunaan obat tidur, didapatkan hasil bahwa seluruh responden yaitu 177 orang (100\%) tidak ada yang menggunakan obat tidur.

Tabel 7. Gangguan aktivitas di siang hari

\begin{tabular}{ccc}
\hline Gangguan Aktivitas & $\mathbf{f}$ & $\%$ \\
\hline Tidak Ada & 18 & 10 \\
Ringan & 58 & 33 \\
Sedang & 79 & 45 \\
Berat & 22 & 12 \\
Total & 177 & 100 \\
\hline
\end{tabular}

Distribusi frekuensi gangguan aktivitas di siang hati terlihat bahwa hanya 18 orang (10\%) yang tidak ada mengeluh mengantuk di siang hari sehingga tidak ada gangguan aktivitas karena tidur yang cukup. Ada159 orang (90\%) mengeluh mengantuk di siang sehingga menyebabkan gangguan ketika beraktivitas di siang harinya, 58 orang (33\%) kategori ringan, 79 orang $(45 \%)$ kategori sedang dan 22 orang (12\%) mengeluh sering mengantuk di siang hari sehingga sangat mengganggu aktivitas di siang harinya.

Hasil penelitian mengenai prestasi akademik menunjukkan bahwa sebanyak 94 orang (53\%) memiliki prestasi akademik yang baik dan sebanyak 83 orang $(47 \%)$ memiliki prestasi akademik yang kurang baik. Gambaran prestasi akademik mahasiswa program studi pendidikan dokter angkatan 2010 FK Unand dapat dilihat pada Tabel 8.
Tabel 8. Gambaran prestasi akademik mahasiswa

\begin{tabular}{ccc}
\hline Prestasi Akademik & $\mathbf{f}$ & Persentase \\
\hline Baik & 94 & $53 \%$ \\
Kurang Baik & 83 & $47 \%$ \\
Total & 177 & $100 \%$ \\
\hline
\end{tabular}

Berdasarkan data yang diperoleh, sebanyak 51 orang (65\%) memiliki kualitas tidur yang baik disertai dengan prestasi akademik yang baik juga dan hanya 27 orang $(35 \%)$ yang memiliki kualitas tidur yang baik tapi prestasi akademiknya kurang baik. Sebaliknya, sebanyak 56 orang $(57 \%)$ memiliki kualitas tidur yang buruk dengan prestasi akademik yang kurang baik dan 43 orang $(43 \%)$ yang memiliki kualitas tidur buruk tapi prestasi akademiknya baik. Analisis bivariat dengan menggunakan uji chi-square, didapatkan nilai $\mathrm{p}=0,004$ $(p<0,05)$ dengan tingkat kepercayaan $95 \%$ sehingga dapat disimpulkan bahwa hipotesis diterima.

Tabel 9. Hubungan kualitas tidur dan prestasi akademik mahasiswa

\begin{tabular}{cccccc}
\hline & \multicolumn{4}{c}{ Prestasi Akademik } & \multirow{2}{*}{ p } \\
\cline { 2 - 4 } Kualitas & \multicolumn{2}{c}{ Baik } & \multicolumn{2}{c}{ Kurang Baik } & p \\
\cline { 2 - 4 } Tidur & $\mathbf{f}$ & $\%$ & $\mathbf{f}$ & $\%$ & \\
\hline Baik & 51 & $65 \%$ & 27 & $35 \%$ & 0,004 \\
Buruk & 43 & $43 \%$ & 56 & $57 \%$ & \\
\hline
\end{tabular}

\section{PEMBAHASAN}

Penelitian yang telah dilakukan terhadap 177 responden, didapatkan hasil bahwa sebanyak 78 orang (44\%) memiliki kualitas tidur yang baik dan 99 orang $(53 \%)$ memiliki kualitas tidur yang buruk. Pada umumnya, responden mengeluh adanya beberapa masalah yang dihadapi dalam beberapa bulan terakhir ketika penelitian berlangsung. Beban yang paling utama adalah harus menyelesaikan skripsi sebagai salah satu syarat untuk mendapatkan gelar sarjana kedokteran. Masalah tersebut, baik dalam perkuliahan maupun di luar perkuliahan dapat menjadi distress yang mengancam jika tidak diselesaikan dengan baik, sebab ketika ada stressor yang datang maka tubuh akan memberikan respon. ${ }^{1}$ Hal ini juga didukung oleh penelitian Nashori dengan hasil adanya hubungan yang signifikan antara kualitas tidur dengan kemampuan memecahkan masalah pada mahasiswa. Semakin baik kualitas tidur mahasiswa, maka 
kemampuan untuk memecahkan masalah juga akan semakin baik. $^{8}$

Hal ini juga telah dibuktikan oleh penelitian yang dilakukan Hadiyanto dimana salah satu dampak yang ditimbulkan ketika adanya stressor pada mahasiswa akan menyebabkan terjadinya gangguan tidur, seperti insomnia sehingga proses belajar menjadi terganggu. ${ }^{9}$ Hal ini juga sesuai dengan penelitian yang dilakukan Reni, yaitu sebanyak 29 responden $(21,8 \%)$ mahasiswa kedokteran mengalami kesulitan tidur karena harus menyelesaikan tugas perkuliahan maupun tugas di luar perkuliahan. ${ }^{10}$ Tugas yang banyak atau hal lain yang bisa menjadi pemikiran terus menerus dapat menimbulkan ansietas (kecemasan) pada individu. Ansietas meningkatkan kadar norepinefrin yang distimulasi oleh saraf simpatis. Perubahan ini menyebabkan berkurangnya periode tidur stadium IV NREM serta perubahan periode tidur lain sehingga kualitas tidur menjadi terganggu. ${ }^{11}$

Berdasarkan data yang telah didapatkan, hanya 35 orang (20\%) yang tidak ada mengeluh gangguan tidur di malam hari.Sebaliknya, 142 orang $(80 \%)$ mengeluh mengalami gangguan tidur di malam hari. Gangguan tidur yang banyak dikeluhkan adalah terbangun di malam hari sehingga sulit memulai tidur kembali dan terlalu merasa kedinginan atau kepanasan di malam hari. Pada periode tidur fase REM, suhu tubuh akan bervariasi sesuai dengan temperatur di sekelilingnya, seperti menggigil atau berkeringat. $^{12} \mathrm{Hal}$ ini sangat erat kaitannya dengan kondisi lingkungan penelitian, yaitu kota Padang yang merupakan salah satu daerah dengan cuaca panas. Hal ini didukung oleh penelitian Dhimas, yaitu suhu lingkungan ternyata mempengaruhi kualitas tidur mahasiswa fakultas keperawatan Universitas Airlangga yang juga termasuk dalam daerah panas. ${ }^{13}$

Berdasarkan uraian di atas, dapat disimpulkan bahwa lebih dari setengah responden memiliki kualitas tidur yang buruk, namun jumlahnya tidak terlalu menunjukkan perbedaan yang signifikan dengan responden yang memiliki kualitas tidur yang baik.

Prestasi akademik dalam penelitian ini diambi dari hasil ujian blok 4.2. Hal ini sesuai dengan sistem pendidikan di FK Unand yang menggunakan sistem PBL (Problem Based Learning), dimana dalam satu semester terdiri dari tiga kali ujian blok yang dilaksanakan setiap tujuh minggu. Penelitian ini juga lebih mudah dilakukan karena waktu pengukuran prestasi sesuai dengan kondisi kualitas tidur responden yang diukur minimal satu bulan terakhir dalam waktu yang bersamaan sehingga hasil yang didapatkan akan lebih akurat.

Berdasarkan analisis univariat yang telah dilakukan terhadap prestasi akademik responden, didapatkan hasil bahwa sebanyak 94 orang (53\%) memliki prestasi akademik yang baik dan 83 orang (47\%) memiliki prestasi akademik yang kurang baik. Pengolahan data dilakukan setelah sebelumnya dipastikan bahwa tidak ada faktor lain yang mempengaruhi prestasi akademik responden, seperti sedang sakit, stress dan sebagainya, kecuali faktor tersebut mempengaruhi kualitas tidur sehingga prestasi akademik menjadi terganggu.Umumnya responden mengatakan lebih semangat dalam belajar, terutama karena merupakan semester terakhir untuk mendapatkan gelar sarjana kedokteran.Hal ini sesuai dengan yang disampaikan Ahmad, bahwa motivasi adalah salah satu faktor yang berperan dalam mencapai prestasi akademik yang baik.Dari uraian di atas, dapat disimpulkan bahwa lebih dari setengah responden memiliki prestasi akademik yang baik, namun perbedaan jumlahnya tidak terlalu signifikan dibandingkan dengan responden yang memiliki prestasi akademik yang kurang baik. ${ }^{14}$

Analisis bivariat yang telah dilakukan dengan menggunakan uji chi-square, didapatkan nilai $p=0,004$ $(p<0,05)$ sehingga dapat disimpulkan bahwa hipotesis diterima, yaitu terdapat hubungan antara kualitas tidur dengan prestasi akademik mahasiswa pendidikan dokter angkatan 2010 FK Unand. Walaupun secara statistik menunjukkan bahwa lebih dari setengah responden memiliki kualitas tidur yang baik dan prestasi akademik yang kurang baik, namun masingmasingnya menunjukkan perbedaan yang tidak terlalu signifikan, yaitu kurang dari $10 \%$.

Hampir sepertiga responden yang memiliki kualitas tidur yang baik dan prestasi akademik yang baik jumlahnya hampir sebanding dengan responden yang memiliki kualitas tidur buruk dan prestasi akademik yang kurang baik pula, masing-masingnya 51 orang $(65 \%)$ dan 56 orang $(57 \%)$. Kemudian, 
responden yang memiliki kualitas tidur yang baik dan prestasi akademik yang kurang baik hanya 27 orang (35\%) dan yang memiliki kualitas tidur yang buruk dengan prestasi akademik yang baik hanya berjumlah 43 orang (43\%). Hal ini dapat disebabkan oleh faktor lain yang dapat mempengaruhi prestasi akademik responden yang tidak berhubungan dengan kualitas tidur, seperti keadaan fisik, psikis, lingkungan keluarga, sosial ekonomi, pergaulan dan lain-lain. ${ }^{11}$ Responden yang memiliki kualitas tidur yang buruk tapi prestasi akademiknya baik dapat disebabkan karena pengaruh jam belajar di malam hari, terutama ketika akan mengikuti tutorial dan ujian sehingga jam tidur menjadi berkurang, namun responden mampu mencapai prestasi akademik yang baik karena belajar dengan giat.

Hasil penelitian ini juga didukung oleh penelitian dengan hasil adanya hubungan antara kualitas tidur dengan proses belajar dan indeks prestasi akademik. Kualitas tidur ditentukan oleh bagaimana seseorang mempersiapkan pola tidurnya di malam hari, kualitas tidur yang buruk dapat mempengaruhi kemampuan konsentrasi belajar sehingga akan berdampak baik terhadap hasil belajar. ${ }^{15}$ Penelitian oleh Indrawati menunjukkan adanya perbedaan konsentrasi belajar yang diakibatkan oleh kualitas tidur yang tidak baik. Orang yang kekurangan tidur menyebabkan kadar $\mathrm{Hb}$ menjadi rendah sehingga menyebabkan gangguan pada proses belajar. ${ }^{16}$

Hasil penelitian terbaru tahun 2013 oleh dokter ahli saraf Bryce Mander dan Matthew Walker di Universitas Berkeley, California membuktikan bahwa dewasa muda yang berusia 18-25 tahun yang memiliki kualitas tidur yang baik akan membantu mengubah ingatan jangka pendek di hippocampus menjadi ingatan jangka panjang yang disimpan di bagian prefrontal cortex. ${ }^{17}$ Hal ini akan menyebabkan daya ingat/memori menjadi lebih baik dan lama. Penelitian yang dilakukan oleh Puspito pada tahun 2009 terhadap mahasiswa kedokteran menyatakan bahwa jika gangguan tidur meningkat, maka prestasi belajar akan menurun. ${ }^{18}$ Proses tidur menghasilkan tenaga yang luar biasa. Tidur akan meremajakan dan memberi energi pada tubuh dan otak serta berpengaruh terhadap kewaspadaan, suasana hati, persepsi, daya ingat, daya pikir/konsentrasi, dan sebagainya. ${ }^{19}$ Hambatan proses belajar pada dewasa muda umumnya diakibatkan oleh rasa mengantuk dan kelelahan ketika mengikuti pelajaran akibat kurang tidur. Hal ini akan menyebabkan berkurangnya kemampuan konsentrasi dalam belajar sehingga akan mempengaruhi prestasi belajar. ${ }^{20}$

\section{KESIMPULAN}

Kualitas tidur mahasiswa pendidikan dokter angkatan 2010 FK Unand lebih dari setengahnya buruk, namun jumlahnya hampir sebanding dengan yang memiliki kualitas tidur yang baik. Prestasi akademik mahasiswa pendidikan dokter angkatan 2010 FK Unand lebih dari setengahnya baik, namun jumlahnya hampir sebanding dengan yang memiliki prestasi akademik yang kurang baik. Kualitas tidur berhubungan dengan prestasi akademik mahasiswa pendidikan dokter angkatan 2010 FK Unand.

\section{UCAPAN TERIMA KASIH}

Terima kasih yang sedalam-dalamnya kepada semua pihak atas bimbingan, arahan dan motivasi dalam penelitian ini.

\section{DAFTAR PUSTAKA}

1. Guyton AC, Hall JE. Texbook of medical physiology. Edisi ke-11. Philadelphia: Elsevier Saunders; 2007.

2. Potter PA, Perry AG. Buku ajar fundamental keperawatan. Jakarta: EGC; 2005.

3. Lanywati E. Insomnia, gangguan sulit tidur. Jakarta: EGC; 2001.

4. Bussye DJ, Reynold CF, Monk TH, Berman SR, Kuffer DJ. The Pittsburgh sleep quality index: a new instrument for psychiatric and research (diunduh 3 Juli 2013). Tersedia dari: URL: HYPERLINK http://sakai.ohsu.ed/acces/content/ brodym/N547A\%20spring08/apendix/PSQI.doc

5. Hidayat AA. Kebutuhan dasar manusia. Jakarta: Salemba Medika; 2009.

6. Susanto H. Meningkatkan konsentrasi siswa melalui optimalisasi modalitas belajar siswa (diunduh 10 Juli 2013). Tersedia dari: URL: HYPERLINK http://www.bpkpenabur.or.id 
7. Sobur A. Psikologi umum. Bandung: Pustaka Setia; 2006.

8. Nashori F. Mencapai puncak prestasi dengan meningkatkan kualitas tidur dan mimpi: perspektif psikologi Islam (diunduh 21 Februari 2014). Tersedia dari: URL: HYPERLINK http://www. journal.uad .ac.id

9. Hadiyanto. Gangguan tidur pada mahasiswa FK Undip (diunduh 3 Maret 2014). Tersedia dari: URL: HYPERLINK http://www.eprints. undip.ac.id

10. Reni. Hubungan stress dengan gangguan tidur (diunduh 20 Februari 2014). Tersedia dari: URL: HYPERLINK http://www.eprints. undip.ac.id

11. Kozier B. Fundamental of Nursing: Concept, Process and Practise. Edisi ke-5. New Jersey: Prentice Hall; 2003.

12. Hirshkowitz M, Hafkin RG, Khanef AS. Normal sleep and sleep disorders. Dalam: Kaplan HI, Sadock BJ. Comprehensive Textbook of Psychiatry. Edisi ke-9. Philadelphia: Lipincott Williams and Wilkins; 2009. hlm. 2152-77.

13. Dhimas. Faktor-faktor yang mempengaruhi kualitas tidur (diunduh 21 Februari 2014). Tersedia dari: URL: HYPERLINK http://www.unair.ac.id

14. Ahmad. Tidur yang berkualitas (diunduh 20 Agustus 2013). Tersedia dari: URL: HYPERLINK http://faizforindonesia. multiply.com
15. Putri AA. Hubungan antara kualitas tidur dengan konsentrasi belajar dan indeks prestasi mahasiswa program DIII Kebidanan STIKES 'AISYIYAH Yogyakarta (diunduh 21 Februari 2014). Tersedia dari: URL: HYPERLINK http://www.stikes-aisyiyahjogja. ac.id

16. Indrawati V. Pengaruh anemia terhadap konsentrasi belajar anak sekolah dasar (diunduh 21 Februari 2014). Tersedia dari: URL: HYPERLINK http://www.ejournal. unesa.ac.id

17. Mander B dan Walker M. Kualitas tidur dan usia mempengaruhi tugas mengingat otak (diunduh 21 Februari 2014). Tersedia dari: URL: HYPERLINK http://www.Mediapubli ca.co

18. Puspito. Hubungan antara stres dengan kejadian insomnia pada mahasiswa program studi ilmu keperawatan Universitas Dioponegoro (diunduh 20 Februari 2014). Tersedia dari: URL: HYPERLINK http://eprints. undip.ac.id

19. Maas JB. Power sleep: kiat-kiat sehat untuk mencapai kondisi dan prestasi puncak (diunduh 5 Januari 2014). Tersedia dari: URL: HYPERLINK http://www.journal.uad. ac.id

20.Naja AH. Pendidikan berkualitas dan pembangunan SDM. Jakarta: Universitas Indonesia; 2006. 